\title{
Route, early or energy? ... Protein improves protein balance in critically ill patients
}

\author{
Peter J. M. Weijs $1,2,3,4$ \\ See related research by Rehal et al. https://ccforum.biomedcentral.com/articles/10.1186/s13054-017-1892-x
}

Keywords: Protein, Energy, Muscle, Protein balance, High protein feeding, Hypocaloric feeding

The critical care community still has mixed feelings when considering the optimal nutrition of intensive care unit (ICU) patients, which is understandable as randomized controlled trials have not been very helpful in improving clinical practice. There have been no randomized controlled trials (RCTs) to contribute to the discussion, especially concerning the role of enterally fed protein in optimal critical care.

Recent studies on the route of feeding have shown that enteral nutrition (EN) is not necessarily superior to parenteral nutrition (PN) $[1,2]$. There appears to be a strong consensus, with backup from a meta-analysis, on the preferential use of EN over PN [3]. The infection rate was especially used as an argument; however, this is not substantiated in recent trials $[1,2]$. We have to consider how applicable this current knowledge is to all ICU patients.

Early EN is still the preferred way of feeding [3]. Starting feeding early may improve the outcome of ICU patients. RCTs have all investigated (supplemental parenteral) energy delivery [4]. Only two trials have 'considered' protein: the PERMIT trial [5] (protein supplemented, equal level) and EAT-ICU trial [6] (protein supplemented, higher level). Early energy delivery should be applied cautiously since it appears to be related to worse outcome in ICU patients [7-9]. Therefore, and from the perspective of clinical practice, the Swiss Supplemental PN (SPN) trial appears to provide the most logical design [10] - start with early EN and evaluate on day 3 what the level of energy delivery is; when delivery levels are low $(<60 \%)$ start supplementation PN. In clinical

\footnotetext{
Correspondence: p.weijs@vumc.nl

${ }^{1}$ Department of Intensive Care Medicine, VU University Medical Center, Amsterdam, The Netherlands

2Department of Nutrition and Dietetics, Internal Medicine, VU University Medical Center Amsterdam, De Boelelaan 1117, 1081, HV, Amsterdam, The Netherlands

Full list of author information is available at the end of the article
}

practice in our ICU the enteral feeding levels are high enough to avoid PN supplementation, which therefore restricts the specific indication to use PN.

The focus of this research has been caloric delivery. There are more than enough observational data to support that higher protein delivery is associated with improved outcome in ICU patients [7-9]. These observational studies clearly show the benefit of higher protein delivery. However, they are considered relatively weak evidence since illness is considered a confounding factor in the relationship between delivery and outcome for which we cannot completely adjust. Randomized trials have not been conducted, although two trials with randomized high(er) amino acid infusion are available and somewhat contradicting $[11,12]$. As with the studies on caloric delivery, the studies on protein have been hampered by insufficient knowledge on energy and protein metabolism under these (patho)physiological circumstances in the ICU patient [7-9].

Therefore, mechanistic studies on the protein physiology in ICU patients is an essential and current development. The Swedish group of Wernerman and Rooyackers has provided crucial information on the topic. They showed that it was possible to change protein balance during the early phase of admission to the ICU from negative to positive by a short-term (3-h) high-level ( $1 \mathrm{~g} / \mathrm{kg} /$ day $)$ amino acid (AA) infusion [13]. This observation was very important to help understand the physiology since it showed that, under these circumstances of critical illness, some basic principles of nutrition still perform well.

In the December 2017 issue of Critical Care, Sundstrom et al. showed that the effect of supplemental AA infusion at $3 \mathrm{~h}$ is still present at $24 \mathrm{~h}$ [14]. Why is this so important to know? We know from extensive studies in sports and the elderly that protein synthesis can be stimulated by bolus 
protein feeding; however, we know relatively little about the effects of continuous (low dose per time unit) feeding. While the absolute levels of protein balance still have to be considered with caution (e.g., choice of tracer), and we are not completely sure where the protein is going, we now know this positive effect on protein balance is lasting.

The next challenge is to reconnect this physiological information with the outcome of ICU patients. We have shown that muscle (protein) mass at admission to the ICU is relevant for the outcome of ICU patients [15]. We do not know if we can change muscle mass and outcome of ICU patients with protein nutrition. The study by Sundstrom et al. [14] is very promising for protein balance, but will that be enough to change outcome? And, if so, is that true for all patients-does one size fit all?

The ICU patient group is heterogeneous. Earlier, we found high protein delivery to be associated with lower mortality, except for sepsis patients and patients with early caloric overfeeding [7]. The EAT-ICU trial did not find an effect of early goal-directed feeding on physical component score at 6 months or on mortality [6]. Goaldirected feeding included feeding energy based on indirect calorimetry and protein up to $1.5 \mathrm{~g} / \mathrm{kg} /$ day from day 1. Feeding calories up to the measured caloric target from day 1 may be equal to caloric overfeeding [7]. The $47 \%$ of patients with sepsis in the EAT-ICU trial might also not benefit from the higher protein feeding [7]. Therefore, the effects of protein and energy cannot be assessed individually from this trial. Ferrie et al. showed interesting differences in muscle mass and function between an AA infusion rate of 0.8 and $1.2 \mathrm{~g} / \mathrm{kg} / \mathrm{day}$ [12], but not all patients are equal-one size does not fit all! Those patients with a low protein reserve (low muscle mass) may be at highest risk in the ICU and may benefit more from intervention with early protein nutrition.

We have to await further studies, including randomized studies and post-hoc observational studies, to further develop this area of interest. The studies trying to understand the mechanism behind the physiological effect are important as well; we might come nearer to the truth of what works and what does not work in ICU nutrition.

\section{Acknowledgements}

Not applicable.

\section{Funding}

Not applicable.

\section{Availability of data and materials}

Not applicable.

\section{Authors' contributions}

The author read and approved the final manuscript.

Authors' information

Not applicable.
Ethics approval and consent to participate

Not applicable.

\section{Consent for publication}

Not applicable.

Competing interests

PJMW has received funds from Baxter, Fresenius, Nestle, and Nutricia.

\section{Publisher's Note}

Springer Nature remains neutral with regard to jurisdictional claims in published maps and institutional affiliations.

\section{Author details}

${ }^{1}$ Department of Intensive Care Medicine, VU University Medical Center, Amsterdam, The Netherlands. ${ }^{2}$ Department of Nutrition and Dietetics, Internal Medicine, VU University Medical Center Amsterdam, De Boelelaan 1117, 1081, HV, Amsterdam, The Netherlands. ${ }^{3}$ Department of Nutrition and Dietetics, Faculty of Sports and Nutrition, Amsterdam University of Applied Science, Amsterdam, The Netherlands. ${ }^{4}$ Amsterdam Public Health research institute, VU University Medical Center, Amsterdam, The Netherlands.

Received: 12 March 2018 Accepted: 16 March 2018

Published online: 14 April 2018

\section{References}

1. Reignier J, Boisramé-Helms J, Brisard L, Lascarrou JB, Ait Hssain A, Anguel N, Argaud L, Asehnoune K, Asfar P, Bellec F, Botoc V, Bretagnol A, Bui HN, Canet E, Da Silva D, Darmon M, Das V, Devaquet J, Djibre M, Ganster F, Garrouste-Orgeas M, Gaudry S, Gontier O, Guérin C, Guidet B, Guitton C, Herbrecht JE, Lacherade JC, Letocart P, Martino F, Maxime V, Mercier E, Mira JP, Nseir S, Piton G, Quenot JP, Richecoeur J, Rigaud JP, Robert R, Rolin N, Schwebel C, Sirodot M, Tinturier F, Thévenin D, Giraudeau B, Le Gouge A, NUTRIREA-2 Trial Investigators; Clinical Research in Intensive Care and Sepsis (CRICS) group. Enteral versus parenteral early nutrition in ventilated adults with shock: a randomised, controlled, multicentre, open-label, parallel-group study (NUTRIREA-2). Lancet. 2018;391(10116):133-43.

2. Harvey SE, Parrott F, Harrison DA, Bear DE, Segaran E, Beale R, Bellingan G, Leonard R, Mythen MG, Rowan KM, CALORIES Trial Investigators. Trial of the route of early nutritional support in critically ill adults. N Engl J Med. 2014;371(18):1673-84.

3. Reintam Blaser A, Starkopf J, Alhazzani W, Berger MM, Casaer MP, Deane AM, Fruhwald S, Hiesmayr M, Ichai C, Jakob SM, Loudet Cl, Malbrain ML, Montejo González JC, Paugam-Burtz C, Poeze M, Preiser JC, Singer P, van Zanten AR, De Waele J, Wendon J, Wernerman J, Whitehouse T, Wilmer A, Oudemans-van Straaten HM, ESICM Working Group on Gastrointestinal Function. Early enteral nutrition in critically ill patients: ESICM clinical practice guidelines. Intensive Care Med. 2017:43(3):380-98.

4. Singer P, Hiesmayr M, Biolo G, Felbinger TW, Berger MM, Goeters C, Kondrup J, Wunder C, Pichard C. Pragmatic approach to nutrition in the ICU: expert opinion regarding which calorie protein target. Clin Nutr. 2014;33(2):246-51.

5. Arabi YM, Aldawood AS, Haddad SH, Al-Dorzi HM, Tamim HM, Jones G, Mehta S, Mclntyre L, Solaiman O, Sakkijha MH, Sadat M, Afesh L, PermiT Trial Group. Permissive underfeeding or standard enteral feeding in critically ill adults. N Engl J Med. 2015;372(25):2398-408.

6. Allingstrup MJ, Kondrup J, Wiis J, Claudius C, Pedersen UG, Hein-Rasmussen R, Bjerregaard MR, Steensen M, Jensen TH, Lange T, Madsen MB, Møller MH, Perner A. Early goal-directed nutrition versus standard of care in adult intensive care patients: the single-centre, randomised, outcome assessorblinded EAT-ICU trial. Intensive Care Med. 2017;43(11):1637-47.

7. Weijs PJ, Looijaard WG, Beishuizen A, Girbes AR, Oudemans-van Straaten HM. Early high protein intake is associated with low mortality and energy overfeeding with high mortality in non-septic mechanically ventilated critically ill patients. Crit Care. 2014;18(6):701

8. Zusman O, Theilla M, Cohen J, Kagan I, Bendavid I, Singer P. Resting energy expenditure, calorie and protein consumption in critically ill patients: a retrospective cohort study. Crit Care. 2016;20(1):367.

9. Arabi YM, Casaer MP, Chapman M, Heyland DK, Ichai C, Marik PE, Martindale RG, McClave SA, Preiser JC, Reignier J, Rice TW, Van den Berghe G, van Zanten AR, Weijs PJ. The intensive care medicine research agenda in nutrition and metabolism. Intensive Care Med. 2017;43(9):1239-56. 
10. Heidegger CP, Berger MM, Graf S, Zingg W, Darmon P, Costanza MC, Thibault R, Pichard C. Optimisation of energy provision with supplemental parenteral nutrition in critically ill patients: a randomised controlled clinical trial. Lancet. 2013;381(9864):385-93.

11. Doig GS, Simpson F, Bellomo R, Heighes PT, Sweetman EA, Chesher D,

Pollock C, Davies A, Botha J, Harrigan P, Reade MC. Intravenous amino acid therapy for kidney function in critically ill patients: a randomized controlled trial. Intensive Care Med. 2015;41(7):1197-208.

12. Ferrie $\mathrm{S}$, Allman-Farinelli $\mathrm{M}$, Daley $\mathrm{M}, \mathrm{Smith} \mathrm{K}$. Protein requirements in the critically ill: a randomized controlled trial using parenteral nutrition. JPEN J Parenter Enteral Nutr. 2016;40(6):795-805.

13. Liebau F, Sundstrom M, van Loon LJ, Wernerman J, Rooyackers O. Shortterm amino acid infusion improves protein balance in critically ill patients. Crit Care. 2015;19:106.

14. Sundström Rehal M, Liebau F, Tjäder I, Norberg Å, Rooyackers O, Wernerman J. A supplemental intravenous amino acid infusion sustains a positive protein balance for 24 hours in critically ill patients. Crit Care. 2017;21(1):298.

15. Weijs PJ, Looijaard WG, Dekker IM, Stapel SN, Girbes AR, Oudemans-van Straaten HM, Beishuizen A. Low skeletal muscle area is a risk factor for mortality in mechanically ventilated critically ill patients. Crit Care. 2014;18(2):R12. 